кульшового суглобу показала стабілізацію періодичних рухів на єдиній траєкторії для кожного значення швидкості. Підтверждено можливість керування моделлю та послідовність перетворень сигналів генераторів при керуванні, що вказує на доцільність побудови повної моделі ходи людини.

Представлений варіант керування представлений вперше. Подальша робота направлена на створення стабільної ходьби людини за допомогою ЦГВА для кожного м'язу обох ніг.

Ключові слова: центральний генератор впорядкованої активності, м’язо-скелетна модель, хвороба Паркінсона.

${ }^{1,2)}$ A. D. Shachykov, ${ }^{1)}$ P. Henaff, ${ }^{2)}$ A. P. Shulyak

${ }^{1)}$ University of Lorraine, Nancy, France;

${ }^{2)}$ National Technical University of Ukraine "Igor Sikorsky Kyiv Polytechnic Institute", Kyiv,

Ukraine

NEURO-MUSCULOSKELETAL SIMULATOR OF RHYTHMIC MOVEMENTS OF HUMAN HIP JOINT

\title{
Introduction
}

The presented simulator of human rhythmic movements is based on the original model of central pattern generators (CPG), which generate periodic signals for controlling the muscles of the joint. Current models of parkinsonian movements do not simulate lower structures that obtain signals from decision-making structures in brain and are involved in controlling rhythmic muscle activity. Namely, rhythmic activities are influenced by Parkinson disease the most.

The aim of this work is to simulate human lower limbs to study the effects of Parkinson's disease on walking. Global simulator would consist of three consequent levels-computational models: basal ganglia, network of CPGs, and musculoskeletal lower limbs. The presented work covers second and third levels regarding single hip joint.

\section{Simulator architecture}

The CPG model consists of four layers for four types of neurons. Output signals of a pair of motoneurons are fed to the inputs of the Hill models of two opposite leg muscles. Muscles pull thighbone and musculoskeletal model calculates feedbacks, which are represented by three types of sensory neurons.

The presented work is illustrated by implementation of neuro-musculoskeletal system of right human thigh, controlled by two muscles of the hip joint, Iliopsoas and Glutei. Three types of sensory neurons react to speed of contraction, force, and length of muscles. They affect motoneurons of both own and opposite half-centers.

Modelling results

CPG is able to rhythmically control muscles without upper control from brain. The latter only influences modes of CPG. Phase diagram of the joint showed stable swings after 4 periods of transition from stillness to one swing per 2 seconds. The change in the oscillation frequency of the CPG showed a short transition period before stabilization of the hip swings. The phase diagram of the hip joint showed stabilization of periodic motion on a single trajectory for each speed value.

\section{Conclusions}

Simulation shows symmetrical and smooth swings, with amplitude limited to values of natural gait. Used version of control is presented for the first time. The further work is directed on creation of a stable human gait with CPG models for each pair of muscles for both legs.

Keywords: central pattern generator, musculoskeletal model, Parkinson's disease.

Надійила до редакиії

02 травня 2018 року

Речензовано

17 травня 2018 року

UDK 615.831:615.47; 621.317.01

MODULATION OPTICAL RADIOMETRY IN MEDICAL AND BIOLOGICAL RESEARCH

\author{
${ }^{1)}$ Yanenko O. Ph., ${ }^{1)}$ Shevchenko K. L., ${ }^{2)}$ Golovchanska O. D. \\ ${ }^{1)}$ National Technical University of Ukraine "Igor Sikorsky Kyiv Polytechnic Institute", Kyiv, \\ Ukraine; ${ }^{2)}$ National O. Bogomolets Medical University, Kyiv, Ukraine \\ E-mail: OP291@meta.ua
}

Introduction. Radiometric methods and devices of the radio frequency spectrum that are characterized by high 
sensitivity, are increasingly used in various fields of science and technology for measuring, monitoring and evaluating the parameters of weak signals. To a lesser extent, radiometry is used in optics, despite its significant potential capabilities. The purpose of this study is to create affordable high-sensitivity optical modulation radiometers (OMR) and to consider possible options for their application in medicine, biological research and materials science.

Main part. In the article the possibilities of modulation-switching transformation for construction of highsensitivity radiometric devices of optical range and variants of their use in medicine, biological researches and materials science are considered. The original schemes of optical modulation radiometers (OMR) in combination with light therapy devices are developed, which extends their capabilities and improves the efficiency of treatment technologies. The scheme of the photometric radar meter for the location of poorly transparent materials is considered and the results of experimental studies of samples of biological tissues of plant and animal origin, as well as the interaction of the light flux of different wavelengths with the human body tissues (hand) are given.

Conclusions. The possibilities of switching-modulation transformation for construction of circuits of optical radiometers provide:

1. Significant simplification of structural schemes and the process of measuring the intensity of optical signals, in connection with the use of optoelectronic elements and absence of optical-mechanical components of the measuring path.

2. Extension of the functional capabilities of radiometric equipment in the field of light therapy and medicalbiological studies of poorly transparent materials.

Key words: switching modulating transformation, optical radiometer, light-therapy, light flux intensity.

\section{Introduction.}

\section{Formulation of the problem}

Radiometric methods and tools of the radio-range frequency, which are characterized with high sensitivity, are finding more and more application in the different fields of science and technique. They are used for measurement, control and evaluation of the weak signals parameters in radio astronomy, physics and plasma physics, medicine and biology [1]. The fluctuation sensitivity threshold of the certified mm-range modulation radiometers reaches $10^{-22} \ldots 10^{-21} \mathrm{~W} / \mathrm{Hz}$ [2]. The same radiometers could be used for various equipment with weak level signals checking so as for scientific researches of the low-intensity electromagnetic fields and physical and biologic objects radiation [2].

The modulation method of the input signals transformation is most promising method used for highsensitive radiometers construction. It's easy performing, reliable and provides high sensitivity.

The block diagram of the direct transformation modulation radiometer includes an input duplex switch (modulator), modulation frequency generator and measuring channel in which modulated signal is transforming. The measuring channel consists of the consistently connected amplifier, quadratic detector, selective switching frequency amplifier synchronous detector and low pass filter. Transmitters are connected to the inputs of the switch. In the radio range, the reception antennas are used and in the optical range photoelectric converters are applied.

With two-stroke operation mode of the switch the input signals from the reception antenna or from its equivalent are alternatively transforming in the measuring channel [3]:

$$
\left\{\begin{array}{l}
u_{1}(t)=u_{o}(t)+u_{w}(t) \\
u_{2}(t)=u_{w}(t)
\end{array},\right.
$$

where $u_{o}(t), u_{w}(t)$ - measuring signal and hardware noise.
An algorithm for compensation of own noise which provides a reduction of the fluctuation threshold and increasing of the radiometer sensitivity is implemented in the measuring channel:

$$
u_{3}(t)=u_{1}(t)-u_{2}(t)=u_{o}(t) .
$$

The signal from measuring channel is submitted to analogue or digital indicator.

Radiometric methods are used in optics to a lesser extent, despite its significant potential capabilities. It's connected mostly with complexity of the optical range equipment, its considerable cost and the lack of the high-sensitive devices. Thus, photometric meters of the optical signals parameters, considered, for example, in [4 - 6], use complex specialized means - photometric sphere and light-emitting benches, systems of protection from third-party light sources, optical-mechanical connections, mechanical modulators of light flux. These means significantly complicate the processes of measuring and implementing such equipment.

However, the development of the theoretical foundations and elemental base of optoelectronic technology, appearance of the new semiconductor light sources, highly sensitive diode and transistor photodetectors, optical electronic modulators, new circuit design solutions for the construction of radiometric equipment contribute to its spread, both in the field of optical measurements and in practical use in various fields of science and engineering $[1,7]$.

The aim of this study is to create affordable highly sensitive optical modulating radiometers (OR) and to consider possible options of their application in medicine, biology and material science.

A number of devices and systems for light therapy using wide spectral range: ultraviolet with wavelength $180 \ldots 380 \mathrm{~nm}$, visible $(380 \ldots 780 \mathrm{~nm})$, and infrared $(0,78 \ldots 760$ microns $)$ appeared in medicine recently.

Equipment of the Korobov visible spectrum series "Barva" which uses light diodes with power from 5 to 
$120 \mathrm{~mW}$, is widely used in Ukraine, so as various infrared range lamps, polarized light lamps by famous Swiss company Zepter, UV lamps, laser and LED devices such as UFL - 1, APL - 1, MILTA-F-01, Mustang [8,9] and others. Typically, the power of such equipment is within $10^{-3} \ldots 10^{-2} \mathrm{~W}$.

The method of low-intensity light therapy (LLLT) is also known, it use laser and LED irradiating sources with power from several to tens milliWatt [10]. The feature of LLLT devices, which are known as photobiomodulators, is the transformation of light energy into the metabolic energy of biological functioning of cells. The mechanisms of the low-intensive light therapy are considered in details in [11].

The measurement of the specified power levels usually is performed with build-in photodetector with a simplified scheme. However, sophisticated therapeutic systems for light therapy with feedback, radiation exposure and absorbed dose determination require a more sensitive measuring device based on, for example, an optical radiometer. This requirement in fullest is also applied to scientific research on the interaction of optical radiation with tissues and other weakly transparent substances and liquids [7]. The power of optical signals can thus be 10-9 ... 10-12 W. Such signal level can be compared with power of the hardware noise, their influence during measurement could be reduced by using modulation optical radiometer circuit.

Thus, the list of the tasks to solve in the medical biologic applications and researches by using the modulation optical radiometer should include:
- metrological support and conduction of the light therapy equipment with the wavelength range $\lambda=180 \ldots 780 \mathrm{~nm}$, and power $\mathrm{P} \leq 10^{-2} \mathrm{Wt}$;

- measurement of the interaction parameters of light fluxes with tissues of plant and biological origin and determination of the absorption, reflection and dispersion indicators;

- conduction of tomographic diagnostic researches, determination of pathological abnormalities in the body with high resolution and instrumental sensitivity within $\mathrm{P} \leq 10^{-5} \ldots 10^{-12} \mathrm{Wt}$;

- the study of the interaction of light fluxes of different wavelength with translucent materials and fluids;

- highly sensitive optical spectrum analyzers construction.

The working of the structures of several specialized measuring modulation radiometric circuits for registration and measurement of low intensive optical signals for medical biologic researches were carried out by authors to solve the problems set. ment

Optical radiometer for weak signals measure-

Figure 1 shows the scheme of a highly sensitive optical modulation radiometer developed by the authors [12]. The measuring photodiode 1 and the reference photodiode 2 with a protective sheath 3 are connected to the inputs of the switch 4 of the radiometer.

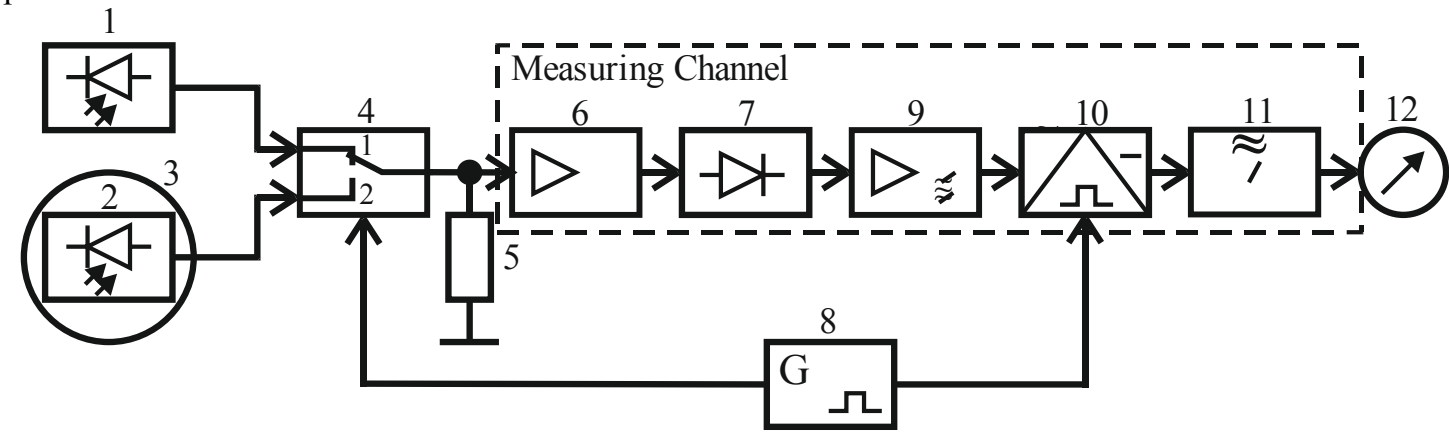

Fig.1. The block diagram of the modulation meter of the intensity of the optical signals

Amplifier 6, detector 7, selective frequency switching amplifier 9, synchronous detector 10, low frequency filter 11 , and indicator 12 make up the measuring channel of the radiometer.

The proposed scheme works as follows. With the help of a rectangular signal of the generator 8 to the input of the measuring channel periodically connected photodiodes 1 and 2 .

At the coordination load 5 in the position of the switch 1 , a voltage proportional to the intensity of the light flux is formed

$$
U_{1}=\left(I_{1}+I_{1}^{\prime}\right) R_{H}+U_{u}=I_{\Sigma} R_{H}+U_{u},
$$

where $I_{1}-$ the current of the measuring photodiode which is equivalent to the intensity of the incoming light flux, $I_{1}^{\prime}-$ dark current of the measuring photodiode, $U_{u}-$ the level of hardware noise of the radiometer brought to its input,

Switching the switch to position 2 leads to the connection of the darkened photodiode 2 to load 5 and the appearance of voltage proportional to the dark current of the reference photodiode $I_{2}^{\prime}$

$$
U_{2}=I_{2}^{\prime} R_{H}+U_{u} \text {. }
$$

For periodic operation of the switch 4 at the output of the measuring channel, a constant voltage is allocated

$$
U_{3}=S_{0} \frac{\left(U_{1}-U_{2}\right)}{2}=S_{0} \frac{1}{2}\left(I_{1}-\Delta I\right) R_{H},
$$


where $S_{0}-$ total conversion rate of the measuring channel; $\Delta I=I_{1}^{\prime}-I_{2}^{\prime}-$ difference of dark currents of photodiodes 1 and 2

From the obtained equation (5) it follows that the intensity of the light flux is proportional to the sum of the output current of the measuring diode and the difference between the dark currents of the measuring and reference diodes. Increasing of sensitivity is also ensured by compensating of own noise of diodes and measuring channel. When using, for example, a photodiode BPV10 in the range of optical signals of $380 \ldots 1100 \mathrm{~nm}$, it is possible to measure the intensity of the optical signal at the level of $10^{-9} \ldots 10^{-10} \mathrm{~W} / \mathrm{cm}^{2}$.

\section{Light therapy device with absorption dose measurement}

Light therapy conducting is always connected with necessity of the determination of the optimal intensity of the illuminating signal, the frequency of modulation of the light flux and its exposure. More correct is the determination of the dose absorbed by the patient's skin, and the maximal absorption frequencies that can predict the effectiveness of the therapeutic procedure. Structure scheme of the device for light therapy in conjunction with an optical radiometer [13] is shown in fig. 2. This device provides irradiation of the patient, measuring the dose of the energy absorbed in the field of radiation on the human body, for example, the biologically active point, and determining the frequencies of maximum absorption of light energy.

The device implements the radar mode and includes: the radiation surface $\mathrm{A}$; generator unit in the generator 1 of impulse rectangle voltage of variable frequency, attenuator 2 and light emitter 3; highsensitive receiver, which includes photodiode 4 , load 5, standard measuring channel OR 6 and indicator 7. LED 3 and photodiode 4 are fixed at the same angles to the plane of the irradiation A.

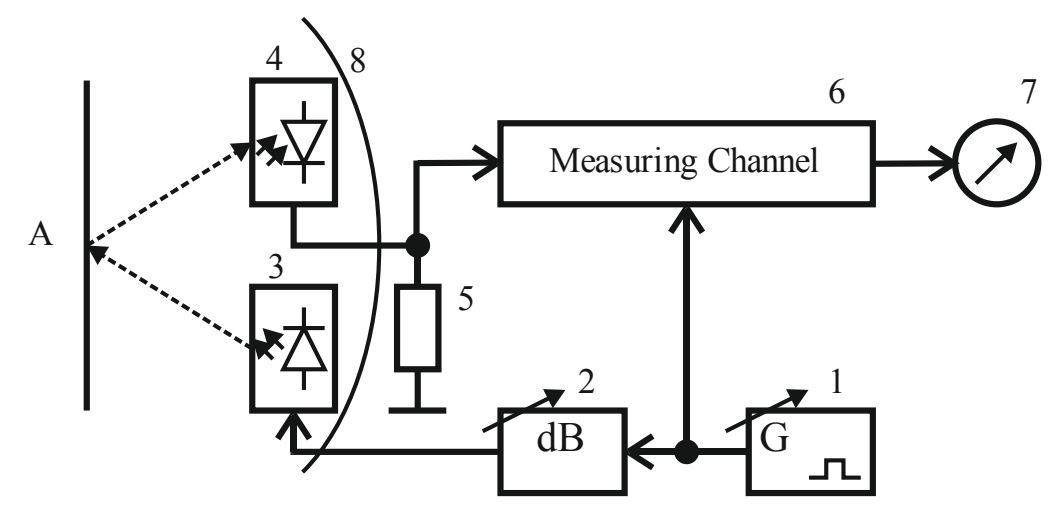

Fig. 2. Light therapy device with absorption dose measurement

Light therapy device works as follows. Initially, in the first stage, the device is calibrated. For this the mirror should be set to point A (focus of the reflector). The signal come in to input of the photodiode and the balance of intensity can be written in the form:

$$
P_{1}=P_{2 \kappa}+P_{3},
$$

where $P_{1}$ - power of the emitter 3 light flux; $P_{2 \kappa}-$ power received by photodiode (reflected from mirror); $P_{3}$ - power of dispersion on the way laser emitter - mirror - photodiode.

When signal of power $P_{2 \kappa}$ is send to the photodiode the photocurrent $I_{1}$, proceeds in the circle photodiode - load 5; this photocurrent is identical to light flux intensity

$$
I_{1 \kappa}^{2} \equiv P_{2 \kappa},
$$

The signal fed to the photodiode periodically under the action of the generator 3 impulses. At the coordination load 5, the voltage dispersion is formed during the passage of the signal

$$
U_{1}^{2}=I_{1 \kappa}^{2} R_{H}+U_{u}^{2},
$$

where $U_{u}^{2}-$ noise dispersion which is brought to the measuring channel input.
In the second half-period, when the signal does not pass, the signal voltage is absent and

$$
U_{2}^{2}=U_{u}^{2}
$$

The voltage packets (8) and (9) are fed adherently to the input of the measuring channel 6 . As the result of this process in the output of the measuring channel for the switching period by the analogy with the equation (5) for calibration mode we get the value:

$$
U_{3}^{2}=S_{0} \frac{\left(U_{1}^{2}-U_{2}^{2}\right)}{2}=S_{0} \frac{1}{2} I_{1 \kappa}^{2} R_{H}=P_{2 \kappa},
$$

In the formula (10) the unknown part of the scattering power $P_{3}$, which physically participates intensity balance according formula (6), is not taken into consideration.

As it's seen from (10), in the output of the OR measuring channel we receive constant voltage which is proportional to power, reflected from the mirror. Its own noises are compensated in the measuring channel by the modulation conversion algorithm.

At the second stage the measurements of the absorption dose while patient irradiated are performed. The skin area (or biological active point - BAP) is 
placed in the focus A of the reflector. The optical signal is fed to the photodiode and intensity balance we can write as

$$
P_{1}=P_{2 u}^{\prime}+P_{3}+P_{4 u},
$$

where $P_{2 u}^{\prime}$ - reflected by the skin to photodiode power; $P_{4 u}$ - absorbed by the skin power.

From the equations (6) and (11), taking into consideration the equality of falling $P_{1}$ and immutability of the scattered power $P_{3}$, by preserving the geometry of the irradiation, determine the absorption power of the area of absorption or BAP

$$
P_{4 u}=P_{2 \kappa}-P_{2 u}
$$

Taking into account the calibration procedure and the equation (10), we obtain

$$
U_{4}^{2}=S_{0} \frac{1}{2}\left(I_{1 \kappa}^{2}-I_{2 u}^{2}\right) R_{H}=P_{2 \kappa}-P_{2 u} .
$$

It is seen from formula (13) that power absorbed by the BAP, is proportional to the difference of the reflected power from mirror during calibration and during irradiation of the skin. The scattering power, which can be $15-20 \%$ of the total intensity of the falling light flux, does not affect the result of the measurement, which greatly increases the accuracy of the measurement of the dose of optical radiation.

In addition, by the changing the frequency of the generator 1 , modulation frequencies with the maximum absorption can be determined, thereby the effectiveness of the light therapy with proposed scheme device will increase.

System for light therapy with absorption dose determination.

The device considered in (13), provides irradiation of the certain areas of the patient's skin, most often BAP. At the same time the necessity of the surface effects on the biologically active zones, wounds surfaces and so on, arises.

Fig. 3 shows an automated microprocessor system for light therapy of the skin surface using a matrix illuminator and the ability to measure the dose of energy absorbed by the skin area [14].

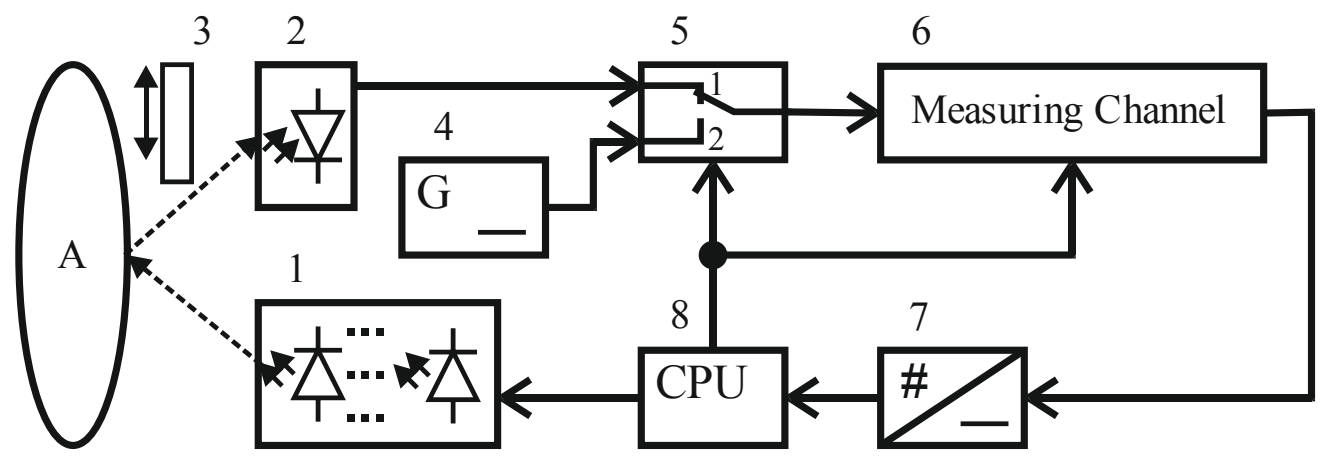

Fig. 3. Simplified scheme of automated system for light therapy with determination of the dose light flux energy absorption

Microprocessor system consist of photodiode matrix 1 , photocell 2, calibration mirror 3 , generator of the reference voltage 4 , commutator 5 , measuring channel 6 , analog-to-digital convertor 7, and computer 8 .

At the first position of the commutator 5 the measurement of the reflected signal from irradiated object is performed

$$
U_{1}=I_{1} R_{H}+U_{T},
$$

where $I_{1}$ - current through the photocell 2 at the maximum light flux intensity of the light matrix $1 ; R_{H}-$ input resistance of the converter current - voltage of the measuring channel, $U_{T}$ - appropriate dark voltage of the photocell 2.

System provides possibility of automatic determination of the absorption dose of the matrix illuminator light flux.

The output voltage of the reference generator 4 is determine by the expression

$$
U_{0}=U_{T}=I_{T} R_{N},
$$

where $I_{T}$ - dark current through photocell 2; $U_{T}$ - appropriate dark voltage.

The reference generator introduction provides compensation of the dark current of the measuring photocell during modulation transformation process, which increases system sensitivity.

Measurement of absorption dose is carried out in two stages. Initially, a system calibration using reflected light from the mirror is performed. The result of outputting ADC 7 in the form of a code $N_{1}$ is stored in the computer memory

$$
N_{1}=S_{0} U_{2}=S_{0} \frac{1}{2}\left(U_{1}-U_{0}\right),
$$

where $S_{0}$ - total conversion rate of the measuring channel.

At the second stage the mirror is removed and the selected skin area of object A is irradiated, resulting in the output of the measuring channel we obtain the voltage value $U_{2}^{\prime}$, from which ADC 7 is formed the code $N_{2}$ :

$$
N_{2}=S_{0} U_{2}^{\prime}=S_{0} \frac{1}{2}\left(U_{1}^{\prime}-U_{0}\right),
$$


where $U_{1}^{\prime}$ - voltage due to intensity of the reflected from irradiation object15; $U_{2}^{\prime}-$ second value of difference voltage.

The difference between the results of calibration and irradiation measurements, which is calculated by computer 8, characterizes absorbed by object of study A part of the photodiode matrix 1 light flux:

$$
N_{3}=N_{1}-N_{2}=S_{0}\left(U_{2}-U_{2}^{\prime}\right) \text {. }
$$

Thus, proposed system is characterized increased sensitivity and measurement accuracy of the light flux power, and at the expense of the developed measurement algorithm - control over the level of energy absorption during the light therapy procedure and, accordingly, ensuring the possibility of the biological effect evaluating and predicting the result of irradiation.

\section{Photometric radar meter for materials sensing}

Measuring of parameters of optical irradiation, which pass through biological tissue or other poorly transparent (cloudy) materials and environments is actual task for such fields as biology and medicine, chemical industry, ecology, food industry and other. The evaluation of the absorption abilities of materials and fluids, the depth of light flux penetration, for example, in biological tissue, and fading factor determination. Measurement of the concentration of a substance in various solutions by the method of determining the light penetration or optical density is widely used in medical technology and environmental research. Optical tomographs for brightening and diagnosing breast cancer in women and the brain in newborn infants are the most secure diagnostic systems [15].
In this case is important the provision of high sensitivity and accuracy of the initial parameters of the light fluxes passing through the investigated materials depth of penetration, coefficient of weakening or absorption. The development of photometric equipment such as colorimeters, spectrophotometers, optical tomographs and others require high sensitivity and resolution, and in the range of optical low-intensity signals [7, 16]. These requirements are met by the modulation methods of transformation of information signals, which, using optical-beam elements, provide highly sensitive spectral analysis in the light therapy processes and medical biological researches.

Fig. 4 shows the simplified scheme of the modulation meter for the study of the reaction of poorly transparent substances and liquids to the irradiation by light fluxes in the range of the optical signals [17].

Highly sensitive modulation meter (spectral analyzer) for sensing materials includes generator unit consisting of microcontroller 1, modulator 2, threepositional switch 3 , semiconductor photodiode matrix of three light sources, receiving portion includes photocell 5 , standard measuring channel 6 , analog-to-digital converter 7 with output connected to computer 8 . The computer output is connected to microcontroller input 1 .

Receiving portion is a high-sensitivity optical radiometer which is installed on a moving carriage.

Structurally, the LED matrix 4 and the photocell 5 are arranged on the same axis, which does not change with carriage movement, which provides the ability to measure the ballistic component of the light flux passing through material. Photometer which measure absorption capacity of the materials works in several stages as follow.

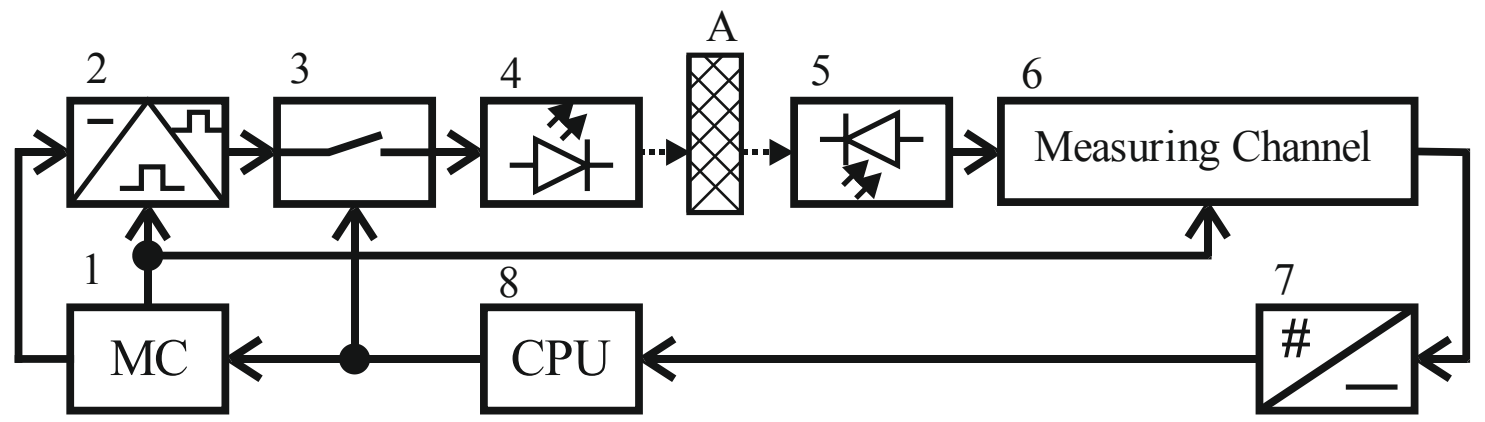

Fig. 4. Simplified scheme of the modulation optical spectrum analyzer

Initially the calibration of the meter is carried out. Carriage with photocell 5 is set at a distance corresponding to investigated material thickness and the signal level from the selected LED is measured according to the standard switching modulation conversion algorithm. Information in the form of code $N_{1}$ is written to the computer. After completion of the calibration, the test material is set and measuring the signal level at the sample output is carried out. Obtaining value in the form of code $N_{2}$ is also fixed in the computer. The ab- sorbance capability of the material for the selected wavelength (light diode) is determined as:

$$
\alpha_{1}=N_{2} / N_{1} \text {. }
$$

The fixed in the computer values of the specified parameters, for example, in the range of visible light from $\lambda_{1}=400 \mathrm{~nm}$ to $\lambda_{2}=700 \mathrm{~nm}$, allow to construct a predicted absorption spectrogram of the test material.

When we determine the absorption coefficient of the material, we can estimate the intensity of light flux passing through the same material of other thickness using Bouguer - Lambert - Ber's formula: 


$$
J_{2}=J_{1}^{-\alpha d},
$$

where $J_{1}, J_{2}$ - intensity of the light flux respectively on input and output material; $\alpha$ - absorption coefficient of the material; $d$-material thickness.

The authors conducted experimental studies of a number of materials of the biological and plant origin

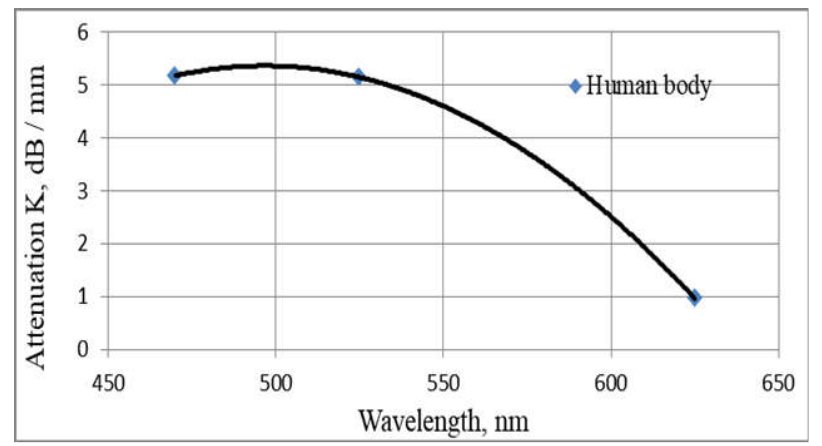

a with the help of considered device. Figure 5 shows the results of the study of the absorption of optical radiation of different wavelengths in soft tissues of the human body in the BAP HE-GU, GI 4 (Fig. 5, a) and samples of the animal tissues (Fig. 5, b).

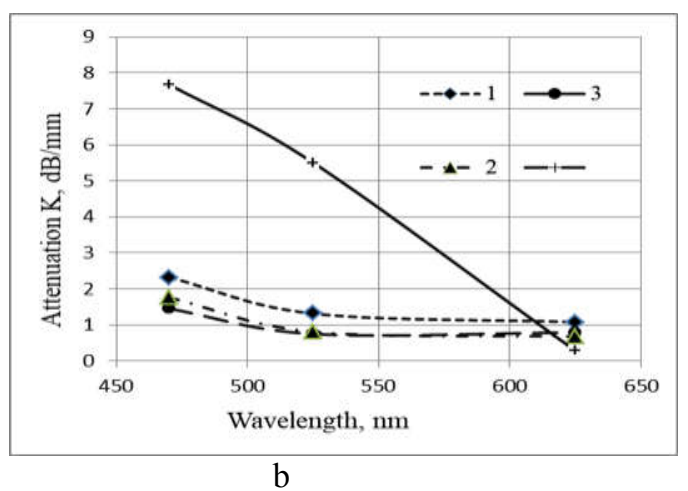

Fig. 5. Spectrograms for the distribution of light fluxes in samples of biological tissues

The methodology of prepared biological tissue of animal origin was as follows. The samples of the adipose and muscle tissues of animals, slaughtered for agricultural purposes, were formed in the same size and thickness with surface skin saved. Irradiation of the samples was carried out in three variants: variants 1 and 3 - through the skin and subcutaneous tissue and variant 2 - only through subcutaneous tissue.

As we can see from Fig. 5, a, in a functional (living) tissue of the human body, the attenuation of the red light flux is at the level $1 \mathrm{~dB} / \mathrm{mm}$, and the attenuation of light fluxes of green and blue is at the level of $5 \mathrm{~dB} / \mathrm{mm}$.

Fig. 5, b shows spectrogram of light fluxes attenuation distribution in the tissues of animal origin. Charts 1, 2 and 3 characterize the light passing through the adipose tissue in the three described above variants. Solid line reflects the distribution of attenuation in the muscle tissue and its form and level almost the same as graph on Fig. $5 \sigma$ a. Light fluxes attenuation in the adipose tissue for different variants of the irradiation, is within the range of $1-2.2 \mathrm{~dB} / \mathrm{mm}$. Free penetration of light fluxes through the adipose tissue is a positive way to perform procedures in patients with excessive weight.

Fig. 6 shows the spectrographs of the light fluxes attenuation in the samples of plant origin - aloe and beet.

The methodology of the aloe samples studies (fig. 6, a): 1 and 2 - irradiation through surface layer and soft tissue and vice versa; 3 - through the integral leaf. From the graphs we can see that minimal attenuation has light flux of the green. A similar form and close absorption coefficients in the whole range of wavelengths also has a spectrogram of light fluxes penetration into a kalanchoe leaves (this isn't ilustrated); so, we can think that such graphs are common for green leaves.

The studies of beet samples give these results (fig. 6, b): lines 1 and 2 -irradiation through the surface layer and strip (tissue) of dark color; lines 2.1 and 3 irradiation pass through the surface layer and strip (tissue) of the light color. The presence of the solid red pigment in the beet tissues lead to abruptly attenuation of the light fluxes and lighting of the tissues - to its significant decreasing (graphs 1,2). The form of the spectrograph on the fig. $6 \mathrm{~b}$ is similar to graph on the fig.5a, this could be explained with the presence in studied tissue red color from blood - hemoglobin. This effect can become a base of the non-invasive method of hemoglobin level determination in the human body.

Using the results of the experimental study, for equation

$$
\beta_{1}=\left(N_{1}-N_{2}\right) / d_{1},
$$

the linear value of absorption which allows to calculate attenuation for similar material of other thickness $d_{x}$ is possible to determine.

\section{Conclusions}

Considered advantages of using switching modulation transformation for optical modulation radiometers construction and variations of their application in medicine, biological studies and material science provide:

1. Significant simplifying of the block diagrams and process of optical signals measuring in connection with use of the optic electronic elements and absence of the optical mechanical components of the measuring path.

2. The measurement of the low intensive optical signals at the level $110^{-9}-110^{-12} \mathrm{~W}$ at the expense of compensation of hardware noise of the optical electronic converter and measuring channel of the OR.

3 . The possibility of construction of the modern devices for light therapy with measuring the dose of the absorbed radiation by selection of reflected and scattered energy which enhances prediction of treatment efficacy.

4. The possibility of the choice of modulation frequencies with maximal absorption of the light flux and the construction of automated systems with frequency scanning of the illuminating signal. 


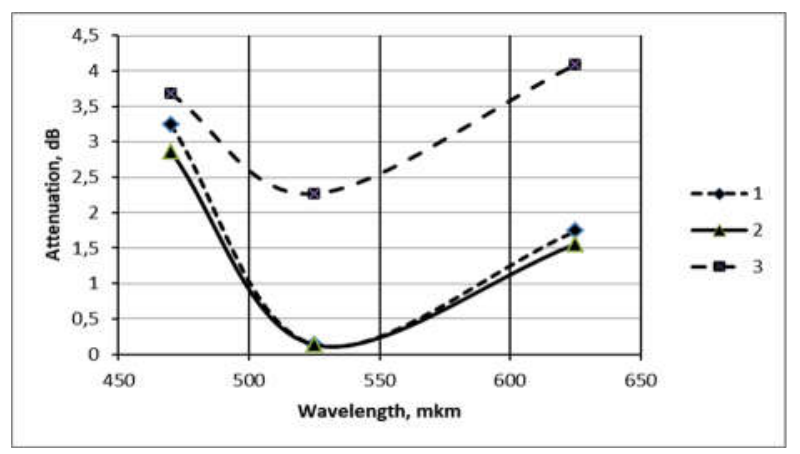

a)

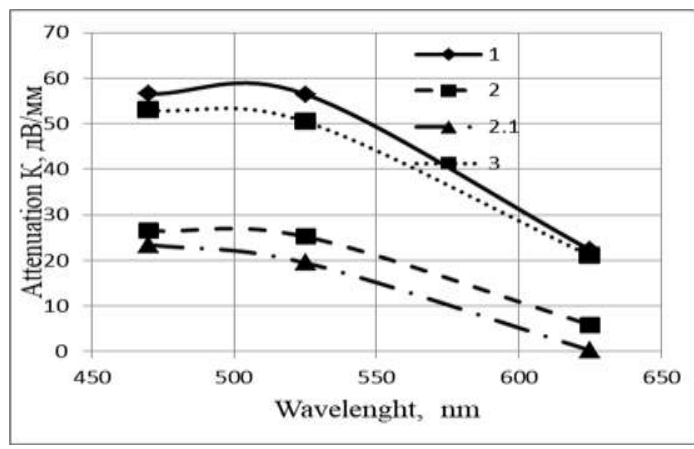

б)

Fig. 6. Spectrographs of distribution of light fluxes in samples of aloe (a) and beet (b) tissues

5. Deepening the possibilities of the medical biological researches by using low-intensity optical signals, by revealing new effects and more modern medical and diagnostic equipment.

\section{Література}

1. 1. Куценко В.П. Методы и средства сверхвысокочастотной радиометрии / В.П. Куценко, Ю.А. Скрипник, Н.Ф. Трегубов, К.Л. Шевченко, А.Ф. Яненко. Донецьк: ІПШІ «Наука і освіта», 2011. 324c.

2. Скрипник Ю.А., Яненко А.Ф., Манойлов В.Ф.Микроволновая радиометрия физических и биологических объектов. Житомир: Волынь, 2003. $408 \mathrm{c}$.

3. Скрипник Ю.А. Измерительные устройства с коммутационно-модуляционными преобразователями. Киев: Вища школа, 1975. С. 256.

4. Кульчицкий А.П., Обринский Л.У. Полевой спектрофотометр, а.с. №1511603, G01, J 3/02, заявл.13.02.87. Опубл.30.09.89, Бюл.№36

5. Фотометр: Пат.на корисну модель Україна. №381107, G01, J 3/42, G01J 3/00, Опубл. 15.05.2001, Бюл. №4.

6. Спектрофотометр: a.c. СССР № 1511602 G01J 3/42. Опубл.30.09.1989, Бюл.№ 36

7. Иванов В.С., Золотаревский Ю.М., Катюк А.Ф. Основы оптической радиометрии. Москва: Физматлит, 2003. 544 с.
8. Медична техніка. Посібник За редакцією проф.. Стеценка Г. С. Луцьк: Надстиря, 2002. 134 с.

9. Попечителев Е. П., Кореневский Н. А. Медицинские приборы, аппараты, системы и комплексы. Часть 4. Курск: КГТУ, 2006. 311 с.

10. Rojas J. C. Low-level light therapy of the eye and brain / J. C. Rojas, F. Gonzalez-Lima // Eye and Brain. - 2011. - No 3. - P. 49-67

11. Hamblin M.R., Demidova T.N. Mechanisms of level linght therapy Proc SPIE; 2006; 6140; p.1-12

12. Фотометричний вимірювач: пат. на корисну модель Україна. №90426 G01J 1/00 Опубл. 26.05.2014, Бюл..№10

13. Пристрій для світло терапії: пат. на корисну модель Україна. №91337 А61Н 39/00, G1J 1|00, Опубл. 25.06.2014p. Бюл. №12.

14. Пристрій для світло терапії: пат. на корисну модель, Україна. Патент № 113732 А61B 5/00 Опубл. 10.02.2017. Бюл. №3.

15. Eggert H., Blazer V. Optical properties of human brain tissue meninges and brain tumors in the spectral range of 200 to $900 \mathrm{~nm}$; Neurosurgery, 1987; 21(4); p.459-464

16. Grimvlatov V., Rubinscein A., Rubinscein M. Spectral djsimetry in low light therapy Proc SPIE; 2006: 6140; p.1-11

17. Фотометричний вимірювач поглинальної здатності слабко прозорих матеріалів: пат. на корисну модель Україна. № 119255 МПК G01J 1/00 Опубл. 25.09..2017p., Бюл. №18.

УДК 615.831:615.47; 621.317.01

\section{${ }^{1)}$ О. П. Яненко, ${ }^{1)}$ К. Л. Шевченко, ${ }^{2)} О$. Д. Головчанська}

${ }^{1)}$ Національний технічний університет Украӥни «Київський політехнічний інститут імені Ігоря Сікорського», Київ, Україна;

${ }^{2)}$ Національний медичний університет ім. О. Богомольия, Київ, Украӥьна МОДУЛЯЦІЙНА ОПТИЧНА РАДІОМЕТРІЯ В ЗАСТОСУВАННЯХ

Модуляційна радіометрія широко використовується в радіотехнічних вимірюваннях, забезпечуючи високу чутливість визначення інтенсивності, яка для шумових сигналів може сягати 1 10-21-1 10-22 Вт/Гц. В статті приводяться відомості щодо використання низькоінтенсивних оптичних сигналів, з інтегральною потужністю 
1 10-9-3 10-12 Вт для терапії, діагностики та поглиблених медико-біологічних досліджень. Авторами розглянуто можливості модуляційно-комутаційного перетворення для побудови високочутливих радіометричних пристроїв оптичного діапазону та варіанти їх використання. Розглянуто схему оптичного радіометра та алгоритм перетворення сигналів з компенсацією шумів радіометричного каналу.

Приводяться оригінальні схеми оптичних модуляційних радіометрів (ОМР) в поєднанні із пристроями для світлотерапії, що розширює їх можливості та підвищує ефективність технологій лікування, в тому числі пристрій для визначення дози поглинутої енергії в процесі проведення світлотерапії й автоматизована радіометрична система із оцінкою поглинання світлового потоку та використанням зворотного зв'язку з об'єктом опромінення.

Розглянуто схему фотометричного радарного вимірювача (спектроаналізатора) для локації слабко прозорих матеріалів, приведено результати експериментальних досліджень зразків біотканини рослинного і тваринного походження, а також взаємодію світлового потоку різної довжини хвиль з тканиною руки людини. Авторські технічні рішення затверджені патентами України. Експериментально показано, яким чином наявність кольорового пігменту в зразках біотканини змінює форму оптичної спектрограми, що може використовуватися для побудови нових методів та засобів фотоаналізу та діагностики.

Ключові слова: модуляційно-комутаційне перетворення, оптичний радіометр, світлотерапія, інтенсивність світлового потоку, біоматеріали.

${ }^{1)}$ А. Ф. Яненко, ${ }^{1)}$ К. Л. Шевченко, ${ }^{2)}$ О. Д. Головчанская

${ }^{1)}$ Национальный технический университет Украины «Киевский политехнический институт имени Игоря Сикорского», Киев, Украина;

${ }^{2)}$ Нацчиональный медиичиский университет имени О. Богомольйа, Киев, Украина МОДУЛЯЦИОННАЯ ОПТИЧЕСКАЯ РАДИОМЕТРИЯ В МЕДИКО-БИОЛОГИЧЕСКИХ ПРИМЕНЕНИЯХ

Рассмотрены возможности модуляционно-коммутационного преобразования для построения высокочувствительных радиометрических устройств оптического диапазона и варианты их использования в медицине, биологических исследованиях и материаловедении.

Приводятся оригинальные схемы оптических модуляционных радиометров (ОР) в сочетании с устройствами для светотерапии, что расширяет их возможности и повышает эффективность технологий лечения.

Рассмотренная схема фотометрического радарного измерителя для локации слабо прозрачных материалов и приводятся результаты экспериментальных исследований образцов тканей растительного и животного происхождения, а также взаимодействие светового потока различной длины волн с тканью руки человека.

Ключевые слова: модуляционно-коммутационное преобразования, оптический радиометр, светотерапия, интенсивность светового потока.

Надійшла до редакиії 12 березня 2018 року

Речензовано

27 березня 2018 року

УДК 615.837 .3

ОЦІНКА ВПЛИВУ УЛЬТРАЗВУКОВОГО ВИПРОМІНЮВАННЯ НА КОАГУЛЯЦІЮ АЛЬБУМІНУ

\author{
${ }^{1)}$ Терещченко М. Ф., ') Васько А. П., ${ }^{1)}$ Шевченко В. В., ${ }^{2)}$ Чухраєв М. В. \\ ${ }^{1)}$ Начіональний технічний університет України «Киӥвський політехнічний інститут

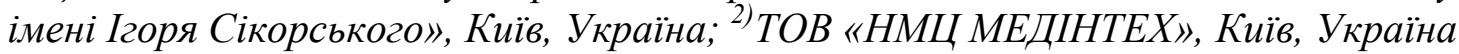 \\ E-mail:agfarkpi@i.ua
}

Проведено дослідження та математичне моделювання впливу ультразвукового випромінювання на коагуляцію альбуміну в біологічному середовищі при змінних показниках інтенсивності й часу дї ультразвуку (УЗ) в немодульованому режимі роботи та різних температурах контактного водного середовища. Визначено параметри впливу УЗ, при яких проявляється початковий процес коагуляиії альбуміну. Встановлено залежність зміни товщини клітинної мембрани білку від часу впливу УЗ випромінювання на досліджуваний об'єкт.

Ключові слова: ультразвук, товщчна клітинної мембрани, коагуляція альбуміну. 